\title{
Oceanography
}

CITATION

Dybas, C.L. 2017. Ripple marks-The story behind the story.

Oceanography 30(2):12-14, https://doi.org/10.5670/oceanog.2017.206.

$\mathrm{DOI}$

https://doi.org/10.5670/oceanog.2017.206

COPYRIGHT

This article has been published in Oceanography, Volume 30, Number 2, a quarterly journal of The Oceanography Society. Copyright 2017 by The Oceanography Society. All rights reserved.

USAGE

Permission is granted to copy this article for use in teaching and research. Republication, systematic reproduction, or collective redistribution of any portion of this article by photocopy machine, reposting, or other means is permitted only with the approval of The Oceanography Society. Send all correspondence to: info@tos.org or The Oceanography Society, PO Box 1931, Rockville, MD 20849-1931, USA. 


\section{Sushi Bait and Switch: What Fish Are You Really Eating?}

By Cheryl Lyn Dybas

identity of a species once it's in the supply chain," says Willette. He and colleagues are working to change that.

\section{TRUTH IN ADVERTISING?}

Willette and other scientists tested 364 samples of 10 popular varieties of fish used for sushi. Running the project for four years was possible in part because it enlisted the help of students from a UCLA class, Introduction to Marine Science.

The researchers visited LA sushi restaurants popular on the reviewing site Yelp and selected specific fish from the menus. When the orders arrived, the biologists asked the servers to confirm each fish name. The scientists then pulled out forceps and scissors, snipped off a piece of the fish, and dropped it into a vial for DNA testing.

The researchers have chosen not to release the identity of the restaurants because they think most sushi eateries would have similar results.

"Time and again, we found species labeled as different fish than what the DNA results showed," says Samantha Cheng, a scientist at UCSB and coauthor of the Conservation Biology paper.

The explanation? Among others, the names of fish caught in foreign countries could be lost in translation, or mislabeling might happen in the country of origin, Cheng says. She encourages people to ask questions about where their fish comes from, and what the specific species is.

\section{FISH RESEARCH IN A RESTAURANT}

Of 43 orders of halibut and 32 of red snapper, the researchers were always served fish other than these species. Salmon was mislabeled, however, only one in 10 times. Spicy tuna roll lovers can rejoice; sushi represented as tuna was usually exactly that.

Over the four-year study, only bluefin tuna was always as listed on menus. While just one of 48 tuna samples wasn't tuna, some samples turned out to be Atlantic bluefin tuna and southern bluefin tuna, classified as endangered. Of nine orders of yellowfin tuna, seven were another tuna, usually bigeye, an overexploited species.

"As sustainable foods become more mainstream," says Cheng, "consumers need to know whether their choices are adding pressure to already overharvested fisheries."

Salmon was largely as represented, with only 6 of 47 orders incorrectly named. But all orders of halibut and red snapper flunked the DNA test. In 9 out of 10 cases, halibut was actually flounder. And 4 in 10 halibut orders were flounder species that are overfished or otherwise threatened.

Red snapper didn't fare much better. It's among the most valuable fisheries in the Gulf of Mexico, "despite having been pronounced overfished as early as the mid1990s," state the biologists in their paper. "Increasingly stringent regulation of red snapper has incentivized species substitution, resulting in rampant mislabeling." The LA sushi restaurant red snapper results reflected that trend.

Samples taken at high-end LA-area grocery stores uncovered similar mislabeling rates, $42 \%$ vs. the $47 \%$ in sush eating places. But the fish switch, the biologists believe, may happen far earlier in the supply chain than when sushi is sold to consumers.

"Fish fraud could be accidental," says Paul Barber, an ecologist and evolutionary biologist at UCLA and senior author of the Conservation Biology paper, "but suspect that in some cases the mislabeling is intentional, though it's hard to know where in the chain it begins. I thought we would discover some mislabeling, but I didn't think it would be as high as we found in some species." 
The fraud undermines environmental regulations limiting overfishing, interferes with consumers' decisions, and introduces unexpected health risks, the researchers say.

Mislabeling can harm people avoiding high-mercury fish, such as pregnant women and young children. In other notable cases, pufferfish sold as monkfish landed consumers in three states in hospitals. And almost one-third of halibut sushi examined in one study were olive flounder, a species that has caused outbreaks of parasitic infections in Japan.

\section{FISH FRAUD: ON THE RISE?}

Opportunities for seafood fraud are increasing, the researchers report. Some 4.5 billion people depend on seafood for nutrition and/or livelihoods, and almost $40 \%$ of the world's captured seafood is internationally traded. The global fish trade is currently valued at more than $\$ 135$ billion, so the stakes are high.

Although some short-term studies have suggested that fish fraud is declining in part due to stricter regulations, the study uncovered consistent mislabeling year after year, indicating that seafood misidentification isn't really improving.

While the current research took place in LA, previous studies have detected similar problems nationwide, suggesting that the findings are widely applicable.
"If we don't have accurate information on what we're buying, we can't make informed choices," Barber says.

It appears, however, that no one really knows where the blame belongs.

Logan Kock, chief sustainability officer of Santa Monica Seafood near LA, has the job of educating the company's customers about correct seafood labeling. Santa Monica Seafood is a fresh and frozen seafood processor and distributor that delivers its wares throughout the Southwest.

The company is committed, says Kock, "to being at the forefront of economic integrity issues regarding species substitution. We take a zero tolerance approach to seafood fraud, and only work with reputable purveyors that have passed a rigorous inspection process. Periodic DNA testing also ensures that we're always delivering exactly what customers ordered."

That being said, he acknowledges that for the industry in general, "there are technical issues with transferring [seafood] across the supply chain accurately and credibly."

The bottom line, Kock says, is that "the pursuit of species purity shouldn't be used to

(right) Seafood display at LA grocer. Photo credit: Demian Willette

(below) Is your sushi what you think it is? scare people away from consuming [seafood] or become so costly in implementation that [DNA] bar-coded seafood traced back to the boat, area, and minute of capture puts it out of reach of most people."

Industry, he says, knows the consequences of fraud "and is deeply concerned about supply chain integrity."

Some businesses are shortening that chain. On the East Coast, Kyle Bowling, Chef de Cuisine at the Sushi Lounge in The Ocean Room at South Carolina's Kiawah Island Golf Resort, says that the restaurant obtains all its seafood, including that destined for the Sushi Lounge, from local purveyors who limit their sales to the greater Charleston area. "They use as much local product as possible," says Bowling, "and bring in all their fish whole and butcher them onsite, which, we feel, eliminates the risk of misidentification."

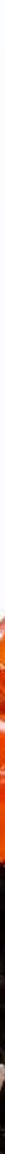




\section{PISCINE BAIT AND SWITCH}

While some mislabeling, says Barber, could be unintentional, sushi fraud might also be driven by attempts to avoid environmental regulations or the chance to sell cheaper fish as more expensive offerings.

Organizations with sustainable seafood guides and certifications-such as the Monterey Bay Aquarium's Seafood Watch Program, the Seafood Choice Alliance, and the Marine Stewardship Council-are important anti-fish fraud consumer resources. The US Food and Drug Administration Seafood List also provides acceptable and common market names for seafood sold in interstate commerce, including information on regulations and food safety hazards for each species.

"However, the success of these programs relies on accurate labeling and traceability of seafood products throughout the supply chain," write the scientists in their paper.
As fish move from harvesters to processors, says Cheng, "reliable labels are supposed to stay with the fish all the way to the point of final sale."

In December 2016, the US National Oceanic and Atmospheric Administration established the US Seafood Import Monitoring Program. It mandates stricter labeling requirements and traceability for fish products coming into the country.

"This is definitely a step in the right direction," says Cheng. "But the personnel conducting these checks will need rapid and accurate identification tools like DNA barcoding to allow them to identify a greater percent of the catch. Scientists need to collaborate with the international and domestic agencies responsible for monitoring and enforcement."

Next up: The researchers hope to test incoming restaurant shipments to find out where in the chain fish such as halibut and red snapper-and those who buy themfirst get entangled in piscine bait-andswitch schemes.

"Business owners, consumers, scientists-all of us-have a shared goal of fisheries sustainability, and job and food security," says Barber. "Otherwise, seafood industries, and the fisheries they depend on, will ultimately disappear." @

Cheryl Lyn Dybas (cheryl.lyn.dybas@gmail.com), a Fellow of the International League of Conservation Writers, is a contributing writer for Oceanography and a marine ecologist by training. She also writes about science and the environment for National Geographic, BioScience, Ocean Geographic, Canadian Geographic, National Wildlife, Yankee and many other publications.

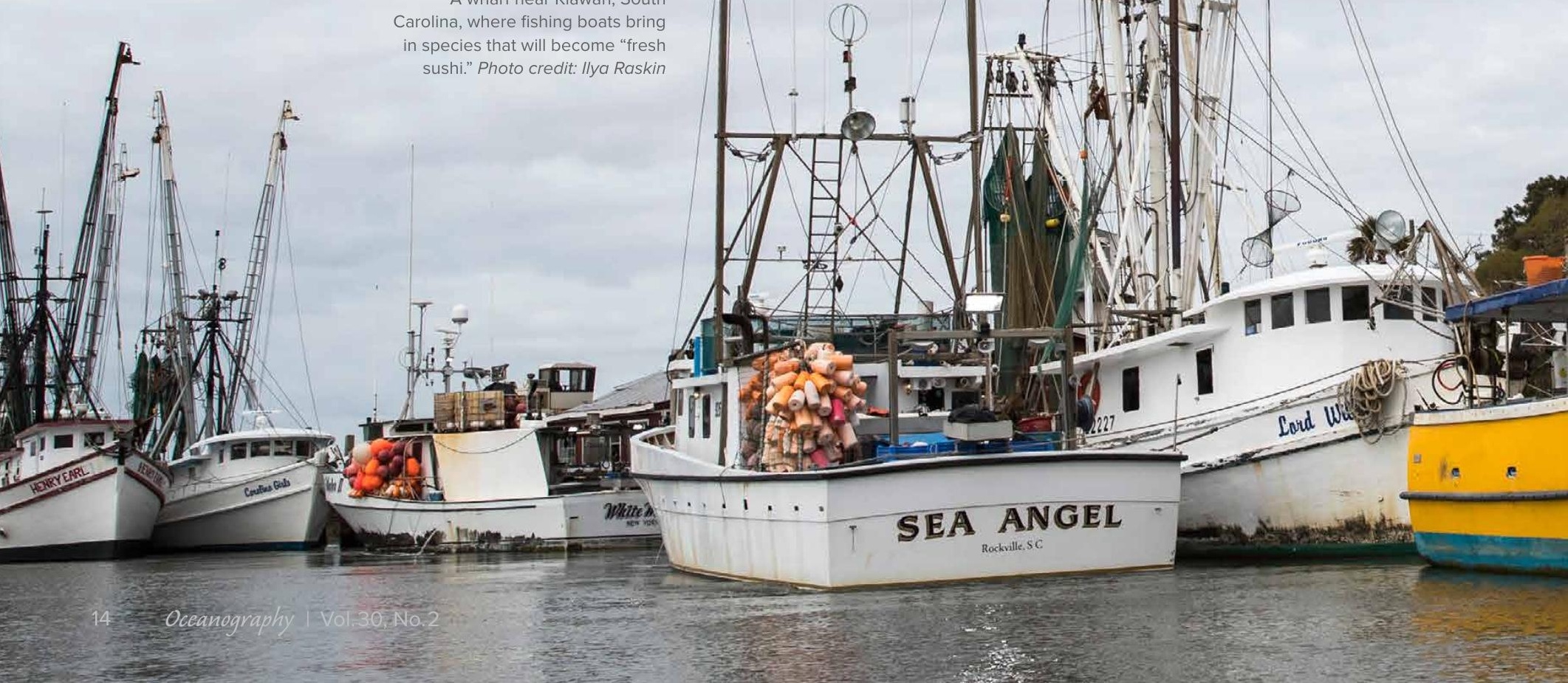

